\title{
Introduction
}

\section{Foreword ... in the tradition of liber amicorum}

\author{
Joseph Marko \\ Professor Emeritus, Institute of Public Law and Political Science, \\ Faculty of Law, University of Graz, Graz, Austria \\ josef.marko@uni-graz.at
}

Benedikt C. Harzl

Assistant Professor, Centre for East European Law and Eurasian Studies (CEELES), Faculty of Law, University of Graz, Graz, Austria benedikt.harzl@uni-graz.at

\section{Aistè Mickonyte}

Senior Scientist, Centre for East European Law and Eurasian Studies (CEELES), Faculty of Law, University of Graz, Graz, Austria aiste.mickonyte@uni-graz.at

The rule-of-law backsliding in Hungary and Poland, troublesome implementation of European anti-discrimination measures, major resistance surrounding international instruments, such as the Istanbul Convention, perceived to be at odds with "traditional values", and even questions of contested statehood, as in Kosovo: Central and Eastern as well as Southeast Europe remain in the focus of academic analysis and media coverage. This issue of the Review of Central and East European Law looks into a multitude of challenges accompanying the processes of Europeanization and the observance of European values as the foundation of political and legal cohesion in the EU and its neighborhood. 
The inspiration for this issue of the Review lies in the works of Hubert Isak, one of the pioneers of EU law at the University of Graz ${ }^{1}$ and beyond. He continues to draw the focus of European-minded scholars on the opportunities and obstacles underpinning the Eastern Enlargement of 2004 and 2007, the EU policy of Eastern Partnership, and subsequent integration of the "new" Member States into the Union of values. The analysis by Hubert Isak points in particular to the fraught process of assessing the actual progress of the candidate countries with respect to the rule of law and democracy. Among his key foci lies the question to what extent the European Union is able and prepared to ensure that the reforms - particularly those related to the rule of law - adopted in anticipation of EU membership are sufficiently robust to be sustained after the accession. ${ }^{2}$ The topics explored in this issue confirm the undiminished - if not increased - relevance of the rule-of-law theme in the region, with Hungary and Poland as notable cases in point.

This year, Hubert Isak is celebrating his $65^{\text {th }}$ birthday. This anniversary has inspired the editorial team as well as the authors featuring in this issue to embrace the long-standing academic tradition of liber amicorum (Festschrift), seeking to honor his contribution to European law with a relentless effort to scrutinize the path of Europeanization in Central and Eastern Europe. Having co-founded the Research Institute of European Law in 1990 at the University of Graz, ${ }^{3}$ the jubilarian has been among the earliest champions of EU law within and beyond the borders of Austria. He has taught EU law as well as international law at the University of Graz, the Diplomatic Academy in Vienna, Danube University Krems, at the Rutgers School of Law and the University of Pittsburg in the US, but also in numerous Eastern and Southeast European countries as well as in the countries of the South Caucasus, such as Georgia; to students but also to judges and practicing lawyers.

In appreciating the scholarly achievements of Hubert Isak, we also mean scholarly activities in a broad sense. With particular fondness do the members of the editorial team recall sharing the teaching activities together with

1 The Research Centre for European Law ("Forschungsinstitut für Europarecht") was co-founded by Hubert Isak in the Faculty of Law of the University of Graz, Graz, Austria, in 199o. Between 1997 and 1999, Professor Hubert Isak was Deputy Director of the Research Institute; he was also Head of the successor Institute of European Law between 1992 and 2002 and between 2003 and 2012.

2 As cited and discussed by Kirsten Schmalenbach in her contribution to this issue (see note 5, at 410), where she discusses Hubert Isak, "Die Binnenverwirklichung von Demokratie und Rechtsstaatlichkeit in der erweiterten Europäischen Union“, in: Peter-Christian Müller-Graff (ed.), Die Rolle der erweiterten Europäischen Union in der Welt (Nomos, Baden-Baden, 2006), at 352 .

3 Currently the Institute of European Law, https://europarecht.uni-graz.at/en/. 
Hubert Isak at a number of international summer schools on EU law as well as European integration in the South Caucasus, which took place at the Shota Rustaveli University of Batumi in Batumi, Georgia, in 2013 and 2014. Reflected in his immensely active role in teaching, Hubert Isak's research extends to the complexities of the interplay between national, European and international law, shedding light in particular on the external action of the European Union, the process of Europeanization and accession in Central and Eastern as well as Southeastern Europe, and the institutional and constitutional foundations of the EU. ${ }^{4}$

Wishing to congratulate the jubilarian and to wish him unrelenting creative energy and interesting new projects, we dedicate this issue of the Review to contributions by Hubert Isak's colleagues, academic friends and students, who, in one way or another, tackle from a multitude of perspectives the themes permeating the jubilarian's activities in the academia. We are confident that in our thanks and best wishes to the jubilarian, a number of friends and colleagues all over Europe are joining us.

This issue offers an in-depth look into the current legal and political challenges charting the state of play in region, perceived primarily from international law and European Union law perspectives. The contributions tackle the EU response to the rule of law crisis in Hungary and Poland; 5 examine the judicial dialogue on Kosovo's independence on a national and international dimension; ${ }^{6}$ discuss the transposition of EU anti-discrimination Directives with reference to case studies in Croatia and other CEE countries; ${ }^{7}$ and presents the debate on the Council of Europe's Istanbul Convention in light of the challenging ratification process in the CEE region. ${ }^{8}$

4 Consider in this regard, e.g., Hubert Isak, "Loyalität und Solidarität in der EU - Einführung. Kommentar zu Einführung und Problemaufriss durch Marcus Klamert“, 70(2) Zeitschrift für Öffentliches Recht (2015), 287-312.

5 Kirsten Schmalenbach, "Defending Democracy and the Rule of Law in the Era of PostEnlargement", 45(4) Review of Central and East European Law (2020), 409.

6 Kushtrim Istrefi, "Contestation of Kosovo's Statehood from Within: EuLEx Judges Adjudicating Privatization Matters through 'Status Neutrality", 45(4) Review of Central and East European Law (2020), 432.

7 Emma Lantschner, "Indicators for Monitoring Implementation of EU Equality Directives", 45(4) Review of Central and East European Law (2020), 444.

8 Elizaveta Samoilova, "The Practices of 'Splitting' and 'Common Accord' Under Scrutiny: the European Parliament's Request for an Opinion of the European Court of Justice on the Istanbul Convention", 45(4) Review of Central and East European Law (2020), 473. 
Kirsten Schmalenbach critically compares the four limbs of EU mechanism for the protection of the rule of law within the European Union: the individual, post-accession mechanism of the rule of law introduced in 2006 for the then new Member States Bulgaria and Romania (first limb); the judicial review by the Court of Justice of the EU (CJEU) (second limb - the strongest according to Schmalenbach); the early-warning framework of 2014 (third limb); and the so-called nuclear option of Art. 7 TEU (fourth limb). As argued, the last option offers much less than the name suggests due to its highly political nature that impedes practical enforcement. The author points to the insufficient institutional response of the Union in addressing the diminishing rule-of-law standards in many Member States.

Moving to Southeast Europe, Kushtrim Istrefi discusses the contestation of Kosovo's statehood by the judges of the EU Rule of Law Mission in Kosovo (EULEX) who deal with privatization matters before Kosovo courts. The author inquires into the contestation of Kosovo's independence by EULEX judges and points to the problems and risks connected to the so-called "status neutrality" policy applied by international organizations in collaboration with Kosovo institutions. According to Istrefi, the policy of "status neutrality" is little more than an attempt to avoid the question of Kosovo's status which only further increases the uncertainty and indeterminacy of Kosovo's position in the international community.

In consideration of case studies involving Croatia, Hungary and Romania, Emma Lantschner subsequently presents, from an empirical viewpoint, the monitoring mechanism of the EU for the implementation of the EU Race Directive $^{9}$ and the Employment Equality Directive. ${ }^{10}$ She discusses the usefulness of indicators in monitoring the transposition and practical implementation of these harmonization measures aimed at curtailing discrimination and promoting the principle of equality. The author emphasizes the potential of non-governmental organizations (NGO s) to contribute to fostering the objectives of the Directives despite the current trends that stand in the way of their involvement. In particular, Lantschner examines the need to apply the indicators not only in the pre-accession period but also as part of the regular monitoring in the Member States.

Finally, Elizaveta Samoilova draws the reader's attention to a pandemic that has been going on long before the COVID-19 crisis, namely the widespread

9 Council Directive 2000/43/EC of 29 June 2000 implementing the principle of equal treatment between persons irrespective of racial or ethnic origin.

10 Council Directive 2000/78/EC of 27 November 2000 establishing a general framework for equal treatment in employment and occupation. 
violence against women. Samoilova discusses the ratification process of the Convention on Preventing and Combating Violence against Women and Domestic Violence (better known as the Istanbul Convention) in the EU and its Member States. The author considers resistance to ratification in Hungary and Bulgaria, but also in Slovakia and other Member States. The issue is approached by shedding light on the practices of "splitting" and "common accord" deployed by EU institutions as well as the importance of choosing the correct legal basis under EU law for adopting an EU measure. Through the lenses of institutional EU law, Samoilova offers a glimpse into the inner workings of the Union against the background of the EU's accession to the Istanbul Convention.

If one should search for a common thread among the above contributions, one would find, in many instances, a call for a coordinated institutional response and supranational checks and balances to counteract the backslide in the rule of law and other obstacles on the rocky path towards the convergence of legal norms under the auspices of Europeanization and the common European values. 